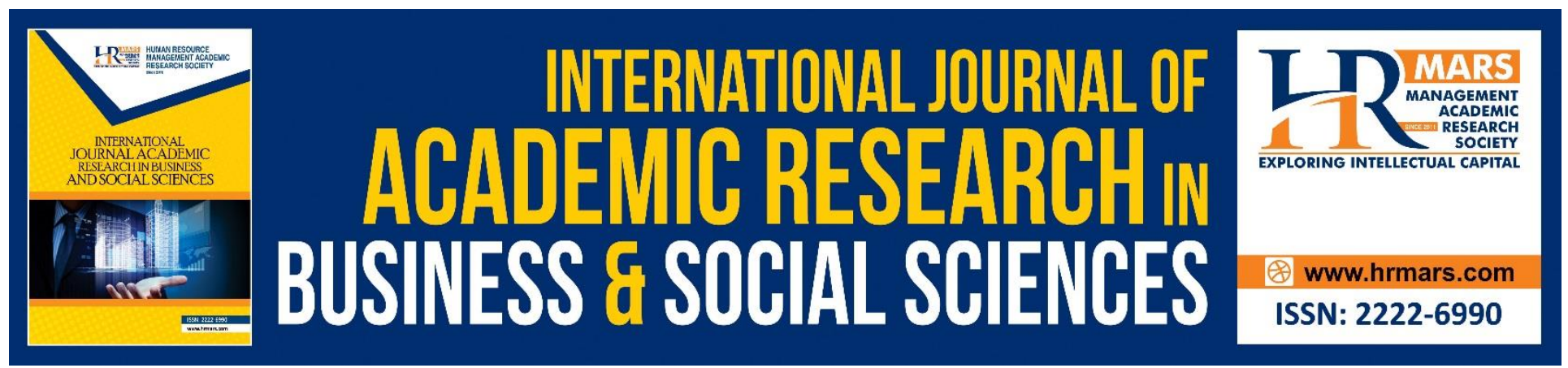

\title{
Factors Influencing Employee Service Quality in a Local Municipal Council in Malaysia
}

Mohd Syafiq Hanis Hamli, Ong Choon Hee, Ong Shze Yin, Rahamah Mahmood

To Link this Article: http://dx.doi.org/10.6007/IJARBSS/v8-i7/4411

DOI: $\quad 10.6007 /$ IJARBSS/v8-i7/4411

Received: 18 May 2018, Revised: 26 June 2018, Accepted: 30 June 2018

Published Online: 21 July 2018

In-Text Citation: (Hamli, Hee, Yin, \& Mahmood, 2018)

To Cite this Article: Hamli, M. S. H., Hee, O. C., Yin, O. S., \& Mahmood, R. (2018). Factors Influencing Employee Service Quality in a Local Municipal Council in Malaysia. International Journal of Academic Research in Business and Social Sciences, 8(7), 677-689.

Copyright: (c) 2018 The Author(s)

Published by Human Resource Management Academic Research Society (www.hrmars.com)

This article is published under the Creative Commons Attribution (CC BY 4.0) license. Anyone may reproduce, distribute, translate and create derivative works of this article (for both commercial and non-commercial purposes), subject to full attribution to the original publication and authors. The full terms of this license may be seen

at: http://creativecommons.org/licences/by/4.0/legalcode

Vol. 8, No. 7, July 2018, Pg. 677 - 689

http://hrmars.com/index.php/pages/detail/IJARBSS

JOURNAL HOMEPAGE

Full Terms \& Conditions of access and use can be found at http://hrmars.com/index.php/pages/detail/publication-ethics 


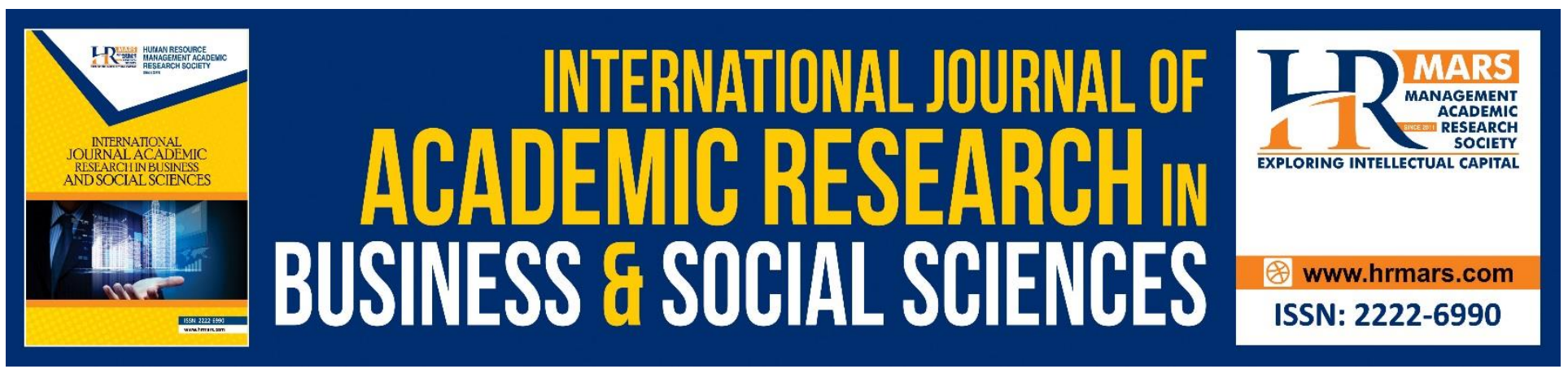

\title{
Factors Influencing Employee Service Quality in a Local Municipal Council in Malaysia
}

\author{
Mohd Syafiq Hanis Hamli, Ong Choon Hee, Ong Shze Yin, \\ Rahamah Mahmood
}

Azman Hashim International Business School, Universiti Teknologi Malaysia, Johor, Malaysia.

Email: msh@live.com.my

\begin{abstract}
This paper aims to analyse the relationship between job satisfaction, transfer of training, perceived organizational support and service quality. Focusing on the factors that influence service quality of employees, the research was set in the context of Malaysian local municipal council. The respondents consisted of specific target departments, divisions and units in a local municipal council which directly provides services to the public in Johor, Malaysia. A quantitative cross sectional survey method was adopted, coupled with factor analysis and multiple regression analysis to analyse the collected data. The findings of this study revealed that job satisfaction and transfer of training were positively and significantly related to consumer purchasing behaviour. Further, job satisfaction was found to be the strongest predictor of service quality of employees. The findings of this research facilitate organization to identify the appropriate employee's factor to be capitalized on and subsequently improved customer satisfaction through high quality of services.
\end{abstract}

Keywords: Job Satisfaction, Transfer Of Training, Perceived Organizational Support, Service Quality.

\section{Introduction}

Service quality has been considered vital for service organization, either public or private. Private sector has adopted this principle much faster compared to public sector due to their primary objective is to maximize profit (Arawati, 2007). However, public services especially local government, realizing the pressures of daunting tasks in providing excellent service and maintaining public satisfaction, has lead their effort to improve quality services continuously (Safiek et al., 2011). Service quality is among the dimensions of local government performance apart from effectiveness, financial growth and customer satisfaction. Service quality is an indicator that measure efficiency and effectiveness of the services deliver to the stakeholders. Local government's roles and responsibilities were governed under The Local Government Act of 1976, which includes providing and maintaining public services such as urban infrastructure, waste management, town planning, public health, building control and social economic development. Numerous previous studies have indicated that there are some factors that have been recognized as antecedents which influence service quality. Those factors can be categorized into three variables namely customer, employee and organization 
INTERNATIONAL JOURNAL OF ACADEMIC RESEARCH IN BUSINESS AND SOCIAL SCIENCES Vol. 8, No. 7, July 2018, E-ISSN: 2222-6990 @ 2018 HRMARS

(Ilhaamie et al, 2013). Customer factor is the demographic factors that are able to influence service quality such as age, gender, working hours, educational level and marital status. These factors affect their perception on service quality. Employee's attitude and behaviour like job satisfaction, employee commitment and citizenship behaviour are among the factors that can influence service quality (Ilhaamie et al, 2013). A study by Malhotra and Mukherjee (2004) has indicated that service quality can be influenced by commitment and job satisfaction. Meanwhile, among the variables that are related to service quality includes organization support, quality programs, service climate and quality culture. Nevertheless, many studies have been conducted previously were focusing on receiver's perspective (customer) whereby only a few studies focusing on employee's perspective. Although customer satisfaction is always the vital aspect in ensuring organization success, employees of the organization are equally important in achieving better service quality (Wan Zahari et al., 2010). It has been noted that there were lots of attention had been emphasized on service quality application particularly in the Malaysian public service sector. However, specific study on local government service quality needs to be investigated based on the environmental and demographical differences among the administrative areas of each local government. Thus, based on the above established concepts, a model that links several elements of employee's factors with service quality was introduced. Quantitative approach was used to test the model and determine which factor has significance influence towards employee's service quality.

\section{Service Quality}

Service quality is commonly defined as an organization capability to fulfil or meet above customer expectations (Safiek et al., 2011). It is between the gap of customer expectations on the service and their perception of the way the service being delivered (Zeithaml et al., 1990). In the public sector perspective, Ahmad Sarji (1991) defined service quality as delivering job duties that provides satisfaction to the public who are the customers to government agency or department. Rowley (1998) defined public sector service quality as customer evaluation on particular entity and its overall excellence. Government in most countries has prioritized service quality as its main focus owing to society demand and taxpayers' expectation on high quality of public services (Wan Yusoff et al., 2008). Parasuraman et al., (1985) established a service quality conceptual model (SERVQUAL) which is also known as Gaps Model. The model was developed to clarify how gaps in service providers' intraorganizational performance led to the gap between customer expectations and perceptions of the service they receive. SERVQUAL is the most often used model to gauge service quality by using the basis of service quality dimensions (reliability, tangibles, responsiveness, assurance and empathy). It was widely being recognized and applied in different contexts. Parasuraman et al., (1985) summarize that, generally, there were five gaps had been identified which are Gap 1: Understanding; this is the difference between actual customer expectation and organization perception towards customer expectation. This gap occurs primarily due to inability of organization to deliver quality services to customer, service features need by customers and the required level of service performance. Gap 2: Design; this is the difference between organization expectation on customer perception and service quality specification. This gap occurs due to management emphasis on other objectives such as cost reduction, short-term gain and take a quality-based approach rather than a consumer approach. Gap 3: Service; this is the difference between service quality specification and the actual service delivery. This gap occurs basically due to the difficulty of following standards or specifications to maintain the service quality. This gap can be referred to as service performance gap where service provider does not perform up to the standard set by the organization. This gap appears when employees unable to 
INTERNATIONAL JOURNAL OF ACADEMIC RESEARCH IN BUSINESS AND SOCIAL SCIENCES Vol. 8, No. 7, July 2018, E-ISSN: 2222-6990 @ 2018 HRMARS

achieve and perform service function at the desired level owing to problems in control system and role conflict. Gap 4: Communication; this is the difference between service delivery and external communication about the service to customers. Communication medium may affect the customer's expectations through promises of more than what they can deliver. Customer's quality impression will be lower when the promise is not met. Most organizations are too fond of pledging more of their capabilities due to increased competition in the service sector. Gap 5 is the difference between expectations of service to service perceptions. This gap occurs when customers are responding to actual service performance in the context of what actually they are expecting. It is the additional size and direction of each gap where it relies upon the nature of the gap correlated with delivery of service quality and service providers. SERVQUAL model is usually being used to measure service quality in the context of customer. Therefore, since the main focal point of this study is all about employee's dimension, therefore, only Gap 3 will only be considered in this study. Further examination on this gap is purposely to identify critical importance of service providers. Since the service of organization is performed or delivered by employees, fundamental reasons that lead to the occurrence of Gap 3 is derived from human resources issues. According to Zeithaml and Bitner (2000), the importance of service providers, front-line employees and office employees are equally vital as they will be evaluated by the customers to determine the success of the organization. Hence, in pursuit of service providers to achieve desirable standard of service quality and perform it continuously, identifying factors that can close the gap is vital. Therefore, based on the above explanation, there is a need to examine the influence of employee's factors towards service quality.

\section{Job Satisfaction}

There is a strong indication that job satisfaction can influence customer's satisfaction (Zeithaml and Bitner, 2000). Job satisfaction is a part of human resource issues that has been found to be a precursor of customer-oriented behaviour (Hoffman and Ingram, 1992). Zeithaml et al., (1990) argued that quality service will not be able to deliver if the employees are not suited to their jobs. Locke (1976) defined job satisfaction as a pleasurable of positive emotional state, resulting from the appraisal of one's job experience. Job satisfaction is among the most researched scope within the management studies (Snipes et al., 2005). There is a commitment for service organizations to concern about job satisfaction (Berry, 1981). Job satisfaction is akin to employee's feelings towards their works. It is also an overall work evaluation for an organization. Job satisfaction can be a tool that could lead to a change of internal environment in terms of employee performance, service quality and customer service improvement. Job satisfaction is essential to attain quality and accountability of an organization (Kusku, 2003). Human relations and job enrichment are among the factors that could stimulate job satisfaction, as well as quality of administration such as work environment (Trivellaset et al., 2009). A model suggested by Schlesinger and Heskett (1991) to examine the relationship between job satisfaction and service quality proposed that job satisfaction leads to employee performance, which subsequently leads to customer satisfaction, loyalty and improving financial performance. Job satisfaction has also been tested in other contexts and it produced positive relationship with service quality in several service industries such as education, banking and hotels (Yoon et al., 2001, Hartline \& Ferrell, 1996, Snipes et al., 2005). It is suggested that the effect on customers' perceived service quality from employee empowerment and job satisfaction is jointly considered an employee-customer relationship within the restaurant industry. The study was conducted based on the model established by Brady and Cronin (2001). It used performance-only index as measurement instead of widely use conceptualization of SERVQUAL model. The results 
INTERNATIONAL JOURNAL OF ACADEMIC RESEARCH IN BUSINESS AND SOCIAL SCIENCES

Vol. 8, No. 7, July 2018, E-ISSN: 2222-6990 @ 2018 HRMARS

suggested that there is a significant relationship between empowerment and job satisfaction with service quality. Hence, based on the above rational explanation, it is hypothesized that:

H1: There is a significant relationship between job satisfaction and service quality.

\section{Transfer of Training}

Training is defined as a planned and systematic effort to provide and enhance employee's knowledge, skills and attitudes related to their job (Blanchard and Thacker, 2010). However, when knowledge, skills and attitudes gained from training were applied consistently, it is referred to as transfer of training (Blume et al., 2010). Transfer of training is considered effective where an employee can transfer and apply what they have learnt consistently and obtained new benefits. Investing more in employee's training and development is able to increase employee's productivity and loyalty (Tsui et al., 1997). Trainings involved in service-oriented problem-solving and interpersonal skills help employees deliver excellent service to the customers. A study of Armistead and Kiely (2003) suggested that employees who were trained effectively, tend to deliver excellent services and significantly raise the customer service level and perception of service quality. Usha et al. (2010) suggested that training inputs help employees remove deficiencies and enhance their capabilities that are essential for organizations in the future. One of the critical determinants for service quality improvement is to build positive perception through the development of suitable competencies and skills of employees (Chung and Schneider, 2002). In order to achieve superior service quality, appropriate training should be designed to produce job competences. However, without proper transfer of training, service quality might not reach its desired level. It is suggested that with proper transfer of training, it can aid employees to fulfil service quality dimensions such as reliability, responsiveness, assurance and empathy. Further, it was found that transfer of training and service quality associates and relates positively. The existence of the relationship is due to the understanding and abilities gained from training which enable them to perform their job well. Therefore, based on the above discussion, it is hypothesized that:

$\mathrm{H}$ 2: There is a significant relationship between transfer of training and service quality.

\section{Perceived Organizational Support}

Perceived organizational support (POS) is defined as the perception level of employees with regard to their organizational recognition towards their contribution and cares for their well-being (Eisenberger et al., 1986, Rhoades and Eisenberger, 2002). Previous studies indicate that when employee feels their employer (organization) values their contribution and cares about their wellbeing, they are inclined to perform well and beyond the specified job requirements (Lavelle et al., 2009). Therefore, perceived organizational support is expected to inspire employees to put higher commitment in delivering service quality. There are several underlying psychological processes and consequences from POS. According to a study of Rhoades and Eisenberger (2002), in the context of reciprocity norm, POS tends to create a felt obligation to care for organization's welfare and assist organization in achieve its objectives. POS regularly involves caring, approval and respect to fulfil socio emotional needs which lead employees to incorporate organizational membership and role status into their social identity. Furthermore, when sufficient POS is practiced, it will help to strengthen employee's acceptance of which organization values and recognizes such as performancereward expectancies. Hence, these processes would yield favourable return for both employees and 
INTERNATIONAL JOURNAL OF ACADEMIC RESEARCH IN BUSINESS AND SOCIAL SCIENCES Vol. 8, No. 7, July 2018, E-ISSN: 2222-6990 @ 2018 HRMARS

organizations which subsequently better the quality of services. In effort to enhance quality of services, it requires synergy between organization and employees. Service quality deteriorates when employees are reluctant or not able to deliver in accordance with the required standard of services (Zeithaml et al., 1990). Therefore, POS has to be well in place to drive better service delivery. For instance, organizations that show full support towards activities related to customer service, are prone to achieve service quality because they emphasizes monitoring and evaluating customer complaint (Saraph et al., 1989). These activities allow organization to gather latest inputs of their service performance. It will further initiate organization to find initiatives to achieve desirable service quality. When an organization emphasizes on fulfilling customer needs and expectations, it will drive the employees to display excellent services with the enhancement of training, recognition and reward. Employees will be more encouraged to perform better if their perceived organizational support is high. Based on the above the discussion, it is hypothesized that:

H3: There is a significant relationship between POS and service quality.

\section{Methodology}

\section{Participants}

This study was conducted in a selected local municipal council in Malaysia. A total of 145 respondents participated in this study. From the responses received, 91 were male respondents and 54 were female. Majority of the respondents were aged between $26-35$ years (67) constitute $46.2 \%$ of the respondents. Respondents aged between 18-25 years old were 27, 26 respondents were aged 46-60 years old and there were 25 respondents aged between 36-45 years old. In terms of years of experience, $33.1 \%$ of the respondents were having 6-10 years' experience, $26.9 \%$ with $11-15$ years of experience, $20.7 \%$ were in the category of 3-5 years of experience and $19.3 \%$ of the respondents were having 1-2 years of experience.

\section{Method and Instruments}

This study employed quantitative method with cluster sampling technique. The measures of service quality were adapted from Zumrah (2013). Measures for job satisfaction, transfer of training and perceived organizational support were adapted from Irene et al., (2005), Xiao (1996) and Eisenberger et al., (1986). Likert scale was used to measure the level of agreement for job satisfaction, transfer of training and perceived organizational support and service quality. The scale was anchored by 1 (Strongly disagree), 2 (Disagree), 3 (Neither agree nor disagree), 4 (Agree) and 5 (Strongly agree).

\section{Data Analysis}

Data analysis in the present study was conducted by using Statistical Package for Social Science (SPSS). Factor analysis was selected to test the validity of the variables and to assess how well the measures represent the concept being measured (Sekaran and Bougie, 2010). Separately, correlation analysis and multiple regression analysis was used to examine the relationship between job satisfaction, transfer of training, perceived organizational support and service quality.

\section{Results}

\section{Factor Analysis}

The independent and dependent variables were validated using factor analysis. Table 1 depicts the results of Kaiser-Meyer-Olkin (KMO) and Bartlett's Test for the study variables. The values of Kaiser- 
INTERNATIONAL JOURNAL OF ACADEMIC RESEARCH IN BUSINESS AND SOCIAL SCIENCES Vol. 8, No. 7, July 2018, E-ISSN: 2222-6990 @ 2018 HRMARS

Meyer-Olkin for Measuring of Sampling Adequacy (KMO/MSA) were 0.869 and 0.922 for the independent variables and dependent variable. According to Hutcheson and Sofroniou (1999), values of KMO/MSA between 0.8 and 0.9 are great for factor analysis. The Bartlett's Test of Sphericity was statistically significant at the 0.000 level, thus supported the factorability of the correlation matrix. The principal component analysis (PCA) with varimax rotation extracted three (3) components from the independent variables after cross loadings were deleted and factor loading of 0.35 and below were discarded. The rotated factors captured a total of $76.08 \%$ of the variance in which component 1 contributes $52.14 \%$, followed by component 2 at $12.71 \%$, and component 3 at $11.23 \%$. Drawing on the factor analysis results (see Table 2 ), items that loaded on component 1 (4 items) were labelled as perceived organizational support, component 2 (4 items) was named transfer of training and component 3 (3 items) were classified as job satisfaction. Table 3 shows a scale factor of service quality that consists of 9 items. The principal component analysis (PCA) extracted 9 items that captured a total variance of $69.70 \%$ with an Eigenvalue of 6.273 . The values of factor loading for service quality were in the range of 0.770 to 0.880 , whereas there is none of the items were discarded due to cross loading. All the 9 items were loaded on a single factor.

Table 1. Kaiser-Meyer-Olkin (KMO) and Bartlett's Test for Study Variables

\begin{tabular}{ccc}
\hline Factorability Assessment & $\begin{array}{c}\text { Independent } \\
\text { Variables }\end{array}$ & $\begin{array}{c}\text { Dependent Variable } \\
\text { (Service Quality) }\end{array}$ \\
\hline $\begin{array}{c}\text { Kaiser-Meyer-Olkin (KMO) } \\
\text { Measure of Sampling }\end{array}$ & 0.869 & 0.922 \\
Adequacy. & & \\
Bartlett's Test of Sphericity & 1052.976 & 1080.416 \\
Approx. Chi-Square & & 36 \\
df & 55 & .000 \\
Sig. & .000 & \\
\hline
\end{tabular}

Table 2: Factor Analysis for the Independent Variables

\begin{tabular}{cccc}
\hline \multicolumn{4}{c}{ Rotated Component Matrix } \\
& 1 & Component & \\
\hline JS2 & & 2 & .804 \\
JS3 & & .862 \\
JS9 & & .682 \\
TT2 & & .856 & \\
TT3 & & .847 & \\
TT5 & & .745 & \\
TT6 & & .779 & \\
PS4 & .857 & & \\
PS5 & .813 & & \\
PS7 & .867 & & \\
PS8 & .850 & & \\
\hline Eigenvalue & 5.736 & 1.235
\end{tabular}


INTERNATIONAL JOURNAL OF ACADEMIC RESEARCH IN BUSINESS AND SOCIAL SCIENCES Vol. 8, No. 7, July 2018, E-ISSN: 2222-6990 @ 2018 HRMARS

\begin{tabular}{cccc} 
Common Variance (\%) & 52.14 & 12.71 & 11.23 \\
Cumulative (\%) & 52.14 & 64.85 & 76.08 \\
Cronbach's Alpha & 0.924 & 0.882 & 0.776 \\
\hline \multicolumn{3}{c}{ Rotated Component Matrix } \\
\hline \multicolumn{3}{c}{ Table 3. Factor Analysis for Service Quality } \\
\hline \multicolumn{3}{c}{ Component } \\
\hline SQ1 & 1 \\
\hline SQ2 & .868 \\
SQ3 & .825 \\
SQ5 & .842 \\
SQ6 & .853 \\
SQ7 & .770 \\
SQ8 & .880 \\
SQ9 & .868 \\
Eigenvalue & .844 \\
Common Variance (\%) & .755 \\
Cumulative (\%) & 6.273 \\
Cronbach's Alpha & 69.70 \\
\hline
\end{tabular}

\section{Reliability Test}

The reliability test results of the independent variables and dependent variable were indicated in Table 2 and Table 3 respectively. The reliability coefficient (Cronbach's Alpha) for the independent variables namely job satisfaction, transfer of training and perceived organizational support was rated $0.776,0.882$ and 0.924 respectively. Cronbach's Alpha for the dependent variable, service quality was 0.945. All the measures were deemed reliable and consistent throughout the study as the reliability coefficients have exceeded the minimum value of 0.7 as suggested by George and Mallery (2003). These statistical results confirmed the reliability of measurement scales used for this study.

\section{Correlational Analysis}

Pearson correlation analysis was employed to examine the correlation between service quality and the independent variables namely job satisfaction, transfer of training and perceived organizational support respectively. The results in Table 4 were indicating correlations between the dependent variable and independent variables. The results showed that job satisfaction has the strongest correlation with service quality among the four variables $(r=0.602, p<0.01)$ and both transfer of training $(r=0.532, p<0.01)$ and perceived organizational support $(r=0.450, p<0.01)$ were moderately correlated with service quality. 
INTERNATIONAL JOURNAL OF ACADEMIC RESEARCH IN BUSINESS AND SOCIAL SCIENCES Vol. 8, No. 7, July 2018, E-ISSN: 2222-6990 @ 2018 HRMARS

Table 4: Correlation between the Study Variables

\begin{tabular}{ccccc}
\hline & Job Satisfaction & $\begin{array}{c}\text { Transfer of } \\
\text { Training }\end{array}$ & POS & $\begin{array}{c}\text { Service } \\
\text { Quality }\end{array}$ \\
\hline Job Satisfaction & 1 & & & \\
\hline $\begin{array}{c}\text { Transfer of } \\
\text { Training }\end{array}$ & $.485^{* *}$ & 1 & 1 & \\
\hline POS & $.495^{* *}$ & $.551^{* *}$ & 1 & \\
\hline Service Quality & $.602^{* *}$ & $.532^{* *}$ & $.450^{* *}$ & 1 \\
\hline
\end{tabular}

$* *$ Correlation is significant at the 0.01 level (2-tailed).

\section{Regression Analysis}

Table 5 shows the results of Multiple Regression Analysis among the independent variables and service quality. The analysis shows that $44.2 \%\left(R^{2}=0.442\right)$ of the variance of service quality can be explained by the three independent variables of job satisfaction, transfer of training and perceived organizational support. The analysis shows that job satisfaction has a significant positive relationship with service quality $(\beta=0.424, p<0.05)$. Therefore, $\mathrm{H} 1$ was accepted. Next, it was found that transfer of training $(\beta=0.279, p<0.05)$ has a significant positive relationship with service quality. Hence, $\mathrm{H} 2$ was also accepted. On the other hand, it was discovered that perceived organizational support was not associated with service quality $(\beta=0.086, p>0.05)$. Thus, $\mathrm{H} 3$ was rejected. The regression results of the present study indicated that job satisfaction contributed more towards service quality with a standardized coefficient of $\beta=0.424$ if we compare with transfer of training. Therefore, job satisfaction serves as the most influential factor of service quality.

Table 5: Multiple Regression Analysis among Independent Variables and Service Quality

\begin{tabular}{|c|c|c|c|c|c|c|c|c|}
\hline & \multirow[t]{2}{*}{ Model } & \multicolumn{2}{|c|}{$\begin{array}{c}\text { Unstandardized } \\
\text { Coefficients }\end{array}$} & \multirow{2}{*}{$\begin{array}{l}\text { Standardized } \\
\text { Coefficients } \\
\text { Beta }\end{array}$} & \multirow[t]{2}{*}{$\mathrm{t}$} & \multirow[t]{2}{*}{ Sig. } & \multicolumn{2}{|c|}{ Collinearity Statistics } \\
\hline & & $B$ & $\begin{array}{l}\text { Std. } \\
\text { Error }\end{array}$ & & & & Tolerance & VIF \\
\hline \multirow[t]{4}{*}{1} & (Constant) & 1.666 & .250 & & 6.671 & .000 & & \\
\hline & JSCOM & .373 & .067 & .424 & 5.597 & .000 & .690 & 1.449 \\
\hline & TTCOM & .216 & .061 & .279 & 3.542 & .001 & .637 & 1.570 \\
\hline & PSCOM & .058 & .053 & .086 & 1.089 & .278 & .628 & 1.592 \\
\hline
\end{tabular}

\section{Discussion}

The study provides greater understanding on the factors influencing service quality in a local municipal council in Malaysia. Job satisfaction was found to be significantly related to service quality in this study. The significant relationship between job satisfaction and service quality has been empirically proven by various studies (e.g., Kusku, 2003; Schlesinger and Heskett, 1991; Malhotra and Mukherjee, 2004; Yoon et al., 2001; Hartline and Ferrel, 1996; Snipes et al., 2005). Nevertheless, understanding of those numerous studies was limited to the context of private sector and service organizations that are profit-oriented such as banks, restaurants and call centers. In addition, previous studies also specifically gauged service quality from the context of external customers. Interestingly, this study extends the discussion by investigating relationship of job satisfaction on 
INTERNATIONAL JOURNAL OF ACADEMIC RESEARCH IN BUSINESS AND SOCIAL SCIENCES Vol. 8, No. 7, July 2018, E-ISSN: 2222-6990 @ 2018 HRMARS

service quality in the public sector which providing services to the public with internal employees as participants to measure service quality. Next, this study reveals that there is a significant relationship between transfers of training and service quality. This particular finding highlights the significance of transfer of training in influencing service quality. This finding is consistent with a study of Zumrah (2013) where it was reported that there is a positive link between training transfer and service quality in the Malaysian public sector. Training is essential for employees to improve self and organization, but transfer of training is much more vital to ensure whatever benefits gained from the training were applied at the workplace accordingly. The finding of the relationship between transfer of training and service quality also helps to clarify ambiguity in the literature (Chand and Katou, 2007). On the other hand, it was found that in this study that perceived organizational support was not associated with service quality $(\beta=0.086, p>0.05)$. As the result of this study did not support the earlier hypothesis, it is in contrary with the past research findings (Bell \& Menguc, 2002) which stated there is a positive and significant link between perceived organizational support and service quality. One possible explanation with regard to the relationship between these two variables is that perceived organizational support might tend to influence behavior of the employees and positive development of work attitude instead of service quality. Employees who perceived strong support from organization may strengthen their management-employee relationship which leads them to feel comfortable with the workplace environment, but it may or may not stimulate them to improve their work performance such as service quality. Conversely, the insignificant relationship between perceived job satisfaction and service quality possibly means that it might be other factors that may mediate the relationship between those two variables. For instance, the role of organizational citizenship behavior may possess mediating role between perceived organizational support and service quality. It was found that through employee organizational citizenship behavior, it has significant effect on employee's performance such as service quality (Chiang and Hsieh, 2012). When there is strong support from the organization, together with voluntary commitment from employees, service quality can be achieved accordingly.

\section{Limitations and Future Research}

This research was conducted under certain limitations that have to be taken into consideration. Although this study provides empirical results, the data gathered were collected at one point of a time due to time limitation. This study was conducted by using quantitative approach whereby questionnaire survey was being used as a method to collect data. Therefore, future study may contemplate to go deeper into their participants to gather qualitative data. To make it more meaningful, combination of both quantitative and qualitative research methods could be used to provide in-depth and detail explanations of factors influencing service quality of the employees. In addition, future research may consider to expand the research boundary beyond the local municipal council. Alternatively, future research could adopt the conceptual framework developed in this study and apply in different research setting such as other local authorities or other public sector organization in Malaysia.

\section{Conclusion}

This research provides indispensable information to improve our understanding of relationship between job satisfaction, transfer of training, perceived organizational support and service quality in the Malaysian local municipal council. Empirical evidence shown in the study indicates the significant influence of job satisfaction and transfer of training towards enhancement of service quality in the 
INTERNATIONAL JOURNAL OF ACADEMIC RESEARCH IN BUSINESS AND SOCIAL SCIENCES

Vol. 8, No. 7, July 2018, E-ISSN: 2222-6990 @ 2018 HRMARS

organization. Satisfied employees are able to demonstrate higher commitment in delivering quality services to the public. Equally important, training programs should be implemented in the organization with careful planning to ensure they are transferable. Alternatively, important inputs can be extracted from the findings of this study to enhance human capital development and their work attitude in the organization. Necessary investment should be made in a way that it brings favorable return to the organization and upgrade employees' performance in achieving higher level of service quality.

\section{Acknowledgements}

The authors would like to thank the Malaysian Ministry of Higher Education and Universiti Teknologi Malaysia (GUP-Vot: 14J81) for providing financial support to publish this paper.

\section{References}

Ahmad Sarji, A. H. (1991). Perkhidmatan awam yang berkualiti: Towards quality public service, Kuala Lumpur: Institut Tadbiran Awam Negara.

Arawati. A., Sunita. B., Jay. K. (2007). An exploratory study of service quality in the Malaysian public service sector. International Journal of Quality \& Reliability Management. 24(2). 177-190

Armistead, C. and Kiely, J. (2003). Creating strategies for managing evolving customer service, Managing Service Quality, 13(2), 164-70.

Bell, S. J., \& Menguc, B. (2002). The employee-organization, organizational citizenship behaviors, and superior service quality, Journal of Retailing, 78, 131-146.

Berry, L.L. (1981), The employee as a customer, Journal of Retail Banking, 3(1), 33-40.

Blanchard, P.N. and Thacker, J.W. (2010), Effective Training: Systems, Strategies, and Practices,4th ed., Prentice Hall, Boston.

Blume, B., Ford, J., Baldwin, T. and Huang, J. (2010). Transfer of training: a meta-analytic review, Journal of Management, 36(4), 1065-1105.

Brady, M.K., \& Cronin, J.J. Jr. (2001). Customer orientation: Effects on customer service perceptions and outcome behaviors. Journal of Service Research,3(3), 241-251.

Chand, M. and Katou, A.A. (2007). The impact of HRM practices on organizational performance in the Indian hotel industry, Journal of Employee Relations, 29(6), 576-594.

Chiang, C. F., \& Hsieh, T. S. (2012). The Impacts of Perceived Organizational Support and Psychological Empowerment on Job Performance: The Mediating Effects of Organizational Citizenship Behavior. International Journal of Hospitality Management, 3, 180-190.

Chung, B.G. and Schneider, B. (2002). Serving multiple masters: role conflict experienced by service employees. The Journal of Services Marketing, 16(1), 70-87.

Eisenberger, R., Huntington, R., Hutchison, S. and Sowa, D. (1986). Perceived organizational support, Journal of Applied Psychology, 71(3), 500-507.

George, D., \& Mallery, P. (2003). SPSS for Windows step by step: A simple guide and reference 11.0 update $\left(4^{\text {th }}\right.$ ed.). Boston: Allyn \& Bacon

Hartline, M. D., \& Ferrell, O. C. (1996). The management of customer-contact serviceemployees: An empirical investigation. Journal of Marketing, 60, 52-70.

Hoffman, K.D. and Ingram, T.N. (1992), Service provider job satisfaction and customer-oriented performance, Journal of Services Marketing, 6(2), 68-78.

Hutcheson, G. and Sofroniou, N. (1999) The Multivariate Social Scientist: Introductory Statistics Using Generalized Linear Models. Sage Publication, Thousand Oaks, CA. 
INTERNATIONAL JOURNAL OF ACADEMIC RESEARCH IN BUSINESS AND SOCIAL SCIENCES

Vol. 8, No. 7, July 2018, E-ISSN: 2222-6990 @ 2018 HRMARS

Irene G.S, Gloria B.C, Amparo C.T, Beatriz M.V (2005). Relationships among customer orientation, service orientation and job satisfaction in financial services. International Journal of Service Industry Management, 16(5), 497-525.

Kusku, F. (2003). Employee Satisfaction in Higher Education: The Case of Academic and Administrative Staff in Turkey, Career Development International, 8(7), 347-356.

Lavelle, J.J., McMahan, G.C. and Harris, C.M. (2009). Fairness in human resource management, social exchange relationships, and citizenship behavior: Testing linkages of the target similarity model among nurses in the United States, International Journal of Human Resource Management, 20(12), 2419-2434.

Locke, E. A. (1976). The nature and causes of job satisfaction. In M. D. Dunnette (Ed.), Handbook of industrial and organizational psychology (pp. 1297-1343). Chicago: Rand McNally.

Malhotra N., Mukherjee A. (2004). The relative influence of organizational commitment and job satisfaction on service quality of customer-contact employees in banking call centers. Journal of Services Marketing, 18(3), 162-174.

Parasuraman, A., Zeithaml, A.V. \& Berry, L.L. (1985). A conceptual model of service quality and its implications for future research. Journal of Marketing, 49, 41-50.

Rhoades, L. and Eisenberger, R. (2002). Perceived organizational support: a review of the literature, Journal of Applied Psychology, 87(4), 698-714.

Rowley, J. (1998). Quality measurement in the public sector: some perspectives from the service quality literature. Total Quality Management. 9(2\&3), 321-333.

Safiek M, Yaleakho A, Ibrahim M (2011) Municipal service quality and citizen satisfaction in Southern Thailand. Journal of Public Administration and Governance, 1(1).

Saraph, J. V., Benson. P. G. and Schroeder, R. G. (1989). An instrument for measuring the critical factors of quality management. Decision Sciences, 20(4), 810-828.

Schlesinger, L., \& Heskett, L. (1991). Breaking the cycle of failure in service. Sloan Management Review, 32, 17-28.

Sekaran, U., \& Bougie, R. (2010). Research methods for business: A skill-building approach (5th ed.). West Sussex: John Wiley \& Sons.

Snipes, R. L., Oswald, S. L., LaTour, M., \& Armenakis, A. A. (2005). The effects of specific job satisfaction facets on customer perceptions of service quality: An employee-level analysis. Journal of Business Research, 58, 1330-1339.

Tsui, A.S., Pearce, J.L., Porter, L.W. and Tripoli, A.M. (1997). Alternative approaches to the employeeorganization relationship: Does investment in employees pay off? The Academy of Management Journal, 40(5), 1089-1121.

Wan Yusoff, W. Z., Ismail, M. \& Newell, G. (2008). FM-SERVQUAL: A new approach of service quality measurement framework in local authorities. Journal of Corporate Real Estate, 10(2), 130-144.

Xiao, J. (1996). The relationship between organizational factors and the transfer of training in the electronics industry in Shenzhen, China. Journal of Human Resource Development, 7(1), 55-73.

Yoon, M., Beatty, S., \& Suh, J. (2001). The effect of work climate on critical employee and customer outcomes: An employee-level analysis. International Journal of Service Industry Management, 12, 500-521.

Zeithaml, V.A., Parasuraman, A. and Berry, L.L (1990), Delivering Service Quality: Balancing Customer Perceptions and Expectations, Free Press, New York, NY.

Zeithaml, V.A. and Bitner, M.J. (2000), Services Marketing: Integrating Customer Focus across the Firm, 2nd ed., McGraw-Hill, New York, NY. 
INTERNATIONAL JOURNAL OF ACADEMIC RESEARCH IN BUSINESS AND SOCIAL SCIENCES Vol. 8, No. 7, July 2018, E-ISSN: 2222-6990 @ 2018 HRMARS

Zumrah, A. R. (2013). Is job satisfaction enhancing learning-training transfer relationship? Journal of Workplace Learning, 25(8), 543-555. 